\title{
MODERNIZATION IN THE ACADEMIC LIBRARIES
}

\author{
Ms. Ruchita J Joshi
}

\begin{abstract}
:
In the present paper, a researcher will discuss the Academic Libraries in the Digital Era and Best practices for modernizing the library. As we know that, the field of digital libraries brings together participants from many existing areas of research. Currently, the domain lacks a clear agenda Academic Libraries in the digital age of this other area. It is tempting for researchers to think that the field of digital modernizing libraries is a natural outgrowth of an already known field, from a database Development of Academic Libraries or Digital Libraries information, can be present realised as a form of joined records. Since a viewpoint, the field of A Modern Academic Library could appear to be a use of the Academic libraries in the digital era. From a library science perspective, Digital Technologies might be seen as continuing a trend toward library Digitization.
\end{abstract}

Key words: Modernization ,Academic Libraries

\section{Introduction:}

There is no reservation that the digital age has different the way libraries work. An academic library used for research purpose and knowledge. It is modernizing the collection and the interplanetary in which the library functions has been a continuous hunt to keep up with the moving goals and parts of the university. The university strives to provide the most technologically.

\section{Modernizing:}

- 'Were all instructors to realize that the quality of the mental process, not the production of correct answers, is the measure of educative growth, something hardly less than a revolution in teaching would be worked.'

John Dewey, Democracy and Education (1916)

- 'The path of least resistance and least trouble is a mental rut already made. It requires troublesome work to undertake the alteration of old beliefs.'

John Dewey, How We Think (1933)

\section{Academic Libraries :}

As per the Wikipedia, 
An academic library is a library that is attached to a higher education institution which serves two complementary purposes to support the school's curriculum, and to support the research of the university faculty and students.

\section{Growth of Academic Libraries :}

The labours of national bodies like Association of Indian Universities (AIU), All India Council of Technical Education (AICTE), National Assessment and Accreditation Council (NACC), and some individual States and Universities to have contributed to this growth regarding the preparation of some standards and rules for their effective operative.

The Preparation Commission, Expert Associations like ILA and IASLIC and State and Central Governments, also have their share in this development. City and countrywide level Library Networks too have faster the pace of the growth of academic libraries in their ways. The National Knowledge Commission of Govt. of India's Report on Libraries entitled, "Libraries, Gateways to Knowledge: A Roadmap for Revitalization "published in 2007 also directs the future growth of an academic library.

\section{A Current Academic Library :}

Moderately a little changes were achieved since then. The old idea of the Documents focussed librarianship was different to the concentrated radar librarianship. Fresh thoughts like open access, reference facility, library cooperation, records and data facilities stayed developed then established, stonework the way of future growths. The long-standing idea of library facility incomplete to a single library has experienced an unbelievable modification spreading it outside the four walls of a library. Ranganathan's innocuous fourth law, 'Save the time of Reader' has expected different meaning, presenting an impression of the prompt library facility, now seen transported into exercise with the help of various displays of ICT.

\section{Academic libraries in the digital era:}

A glowing recognised library is important for any educational organisation. As a principal point for education, knowledge, and study, it is probable to afford natural information resources. The library is no longer considered as a trinity of books, reader and staff or a storehouse of knowledge.

Nowadays academic libraries are stressed to save their residence as the primary basis of analysis in the face of developing a digital technology. Digital technology has developed not single the method data is packed, managed, stowed, and dispersed, then as well in what way users pursue and admission data. Academic libraries no lengthier limit themselves to print facilities such as collection progress, classification and cataloguing, circulation and orientation facilities, present awareness, selective dissemination, and other bibliographic facilities, but have lengthy their exertions to in disciplinary concepts and computer software and telecommunication engineering technology.

All of this careful crating of the library collection is impractical if the scholars do not come to the library to use. It quite than depend on the impression that the library was required to students learning, academic libraries have absent on, the aggressive, with long and occasionally luxurious publicising movements to let students identify near the resources that the library has to proposal. Other marketing tools for libraries include the library website, a standard Feature of every academic library. 
In seeking to perform more outreach for their patrons, it is essential to get the librarian out of the Library. Anecdotal evidence supports the idea that students are more likely to seek out help if they know someone who works At the library, and "knowing" a librarian is as simple as having interacted with him or her during class. Technology has made this easier; now, library instruction sessions no longer need to be confined to within the walls of the library; with most of the resources students want online, an instruction session can consist entirely of teaching the use of accessible databases (Thull and Hansen, 2009). Toward style an added glowing Originated knowledge, virtual tours of the library using footage conveniently housed either on the library's website or popular video sites can show students how to direct the library already they always set end in it. New highly, since these resources and extra are accessible on the library's website, the learning knowledge does not have to end after the librarian greeneries the room.

All of this has led to a modification in the physical space of the library. The highest success in the conversion of the library from similarity to digital has been the data commons. Though the digital rebellion may have started away on campus due to the overview of computer workrooms in whatsoever structures or spaces were accessible, the material commons can be more than just a computer lab in a library. It develops slightly more than the quantity of its parts by associating the technology that students suppose through the knowledge and data resources that they need to complete their projects.

\section{Digital Technologies :}

This is the age of Digital Technology, and today this created for different communities and in different fields. The meaning Digital technologies are universally, and they are impacting what, where, how and why researcher learns, and who they learn from? Many institutes are using digital technologies like the internet, laptops and tablets to quickly, easily and practically connect students with the huge range of digital services and resources. However, the many benefits of learning with digital technologies are accompanied by some challenges and potential risks for researcher and institutes.

\section{Digitization :}

The Digital library is a viral word now a day. It is newly raising standpoint in the current creation and its future. A part of this view there is some fact to these viewpoints, but nobody addresses the field as an entire and its research schedule. The arena of digital libraries will be imperfect if watched only as a subfield of prior research benefits. To understand its full possible, the field must be watched as a union of subfields from a change of areas joint with added goals, and thus new research issues.

This framework presents for thoughtful around the field of digital libraries and the research issues that are a share of it and validates how these issues touch digital library systems. The recent decades have witnessed tremendous advanced in information technology and its application. The latest technologies offer cheaper price computer processing power, mass storage inexpensive access to high-speed networks and retrieval devices which gives us the ability to create, manipulate, store and transfer large quantities of formation in digital format low cost, electronic publishing and resource sharing activities have become very easy and convenient today. These major changes have led create and develop digital libraries. 


\section{Conclusion :}

As academic libraries move advancing and hold the digital age, we necessity recollect that it is not needed to intemperance materials.Research paper tries to analyze the definition, meaning, and Growth of Academic Libraries etc of digital technology. It also includes Academic libraries in the digital era related to Academic librararies and Terminology. This paper focuse on the role of digital libraries and the research issues in the $21^{\text {st }}$ century. With the help of digital library today, we have reduced maan power. As we know that, this is the age of technology, various softwares and applications made a very easy life. In this paper reserache tried to include the details about The latest technologies, mass storage inexpensive access to high-speed networks and retrieval devices which gives us the ability to create, manipulate, store and transfer large quantities of formation in digital format low cost, electronic publishing and resource sharing activities. To seum up, It can be say that, changes have led create and develop digital libraries. 


\section{REFERENCES:}

Arms, W. Y. (2012). The1990s: the formative years of digital libraries. Library' Hi' Tech, 30(4), 579F591. Doi: 10.1108/07378831211285068.

Arms, Williams Y., "Digital Libraries”, Cambridge, MA: The MIT Press, 2000.

Burrows, T. (2006).Brave New World or plus ça change? Electronic Journals and the Academic Library. Australian'Academic'\&'Research'Libraries, 37(3), 170F178.

Dubnjakovic,A.(2012).Electronic Resource Expenditure and the Decline in Reference Transction Statictics in Academic Libraries. Journal' $O f^{\prime}$ Academic'Librarianship,38(2),94F100. doi:10.1016/j.acalib.2012.01.001

Foltz, J.Barham, B., Chavas, J., \& Kim, K. (2012). Efficiency and technological ournal' of 'Productivity' Analysis, 37(2), 171F186. doi:10.1007/s11123F011F0249F8

Foundations for Digital Libraries. Version 0.98, February 2008

Garett, John R., \& Lyons, Patrica A.’Towards an Electronic Copyright management System” JASIS 44(8), 1999.

Gelfand, M A (1968). University Libraries for Developing Countries. Paris, UNESCO.

Greenstone Training Workshop Material. Web (2002), http://www.greenstone.org

L. Candela et al.: The DELOS Digital Library Reference Model -

Malwad, N.M. et.al (ed). "Digital libraries: dynamic store house of digitized information, New Age International Ltd., 1996

Pitti, D. and Duff, W. M. (2001). Introduction. In Pitti, D. and Duff, W. M., editors, Encoded Archival Description on the Internet, pages 1-6. The Haworth Press, Inc.

Pomerantz, Jeffrey, \&Marchionini, Gary. "The Digital Library as Place," Journal of Documentation, 63(4), 2007, pp. 505-533.

\section{Ruchita J Joshi \\ Research Scholar \\ HNGU, Patan, Gujarat \\ Ruchitajoshi2015@gmail.com}

